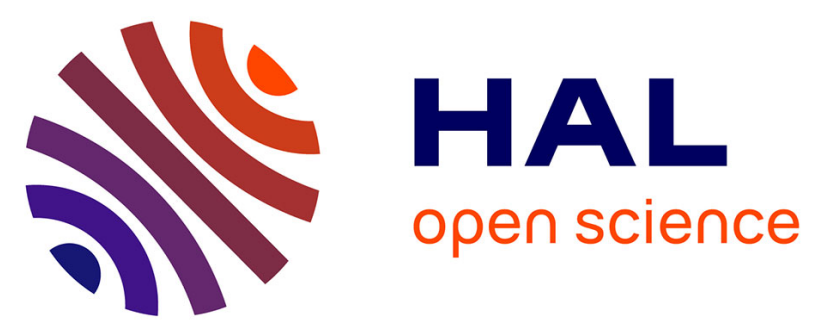

\title{
Fattening performance, metabolic indicators, and muscle composition of bulls fed fiber-rich versus starch-plus-lipid-rich concentrate diets
}

Marie-Madeleine Mialon, Gilles Renand, Isabelle Ortigues Marty, Dominique Bauchart, Jean-François J.-F. Hocquette, Luc Mounier, Thierry Noël, Didier Micol, Michel Doreau

\section{To cite this version:}

Marie-Madeleine Mialon, Gilles Renand, Isabelle Ortigues Marty, Dominique Bauchart, Jean-François J.-F. Hocquette, et al.. Fattening performance, metabolic indicators, and muscle composition of bulls fed fiber-rich versus starch-plus-lipid-rich concentrate diets. Journal of Animal Science, 2015, 93 (1), pp.319-33. 10.2527/jas.2014-7845 . hal-01194029

\author{
HAL Id: hal-01194029 \\ https://hal.science/hal-01194029
}

Submitted on 27 May 2020

HAL is a multi-disciplinary open access archive for the deposit and dissemination of scientific research documents, whether they are published or not. The documents may come from teaching and research institutions in France or abroad, or from public or private research centers.
L'archive ouverte pluridisciplinaire HAL, est destinée au dépôt et à la diffusion de documents scientifiques de niveau recherche, publiés ou non, émanant des établissements d'enseignement et de recherche français ou étrangers, des laboratoires publics ou privés. 


\title{
Fattening performance, metabolic indicators, and muscle composition of bulls fed fiber-rich versus starch-plus-lipid-rich concentrate diets ${ }^{1}$
}

\author{
M. M. Mialon, ${ }^{*}+2,3$ G. Renand, ${ }^{*}$ I. Ortigues-Marty, ${ }^{* \dagger}$ D. Bauchart, ${ }^{*} \dagger$ \\ J. F. Hocquette, ${ }^{* \dagger}$ L. Mounier, ${ }^{*}$ T. Noël, ${ }^{\#}$ D. Micol, ${ }^{* \dagger}$ and M. Doreau ${ }^{* \dagger}$ \\ *INRA, UMR1213 Herbivores, F-63122 Saint-Genès-Champanelle, \\ France; †Clermont Université, VetAgro Sup, UMR1213 Herbivores, BP 10448, F-63000, \\ Clermont-Ferrand, France; †INRA, UMR1313 GABI, F-78352 Jouy-en-Josas, France; §Université de Lyon, \\ VetAgro Sup, UMR1213 Herbivores, F-69280 Marcy l'Etoile, France; and \#INRA, UE0332, F-18390 Osmoy, France
}

\begin{abstract}
The aim of this study was to compare the responses in fattening performance and meat composition for high-concentrate diets rich in either starch and lipids (especially omega-3 fatty acids) or fibrous by-products. A total of 140 Charolais bulls (initially $319 \pm 27 \mathrm{~kg} \mathrm{BW})$ were allocated to 3 high-concentrate diets and were fattened for up to $18 \mathrm{mo}$. The diet treatments included concentrate mixtures rich in either fiber (FR; $n=56$ ) or starch plus linseed (diets SL and SLR; $n=56$ and $n=28$, respectively) and barley straw. The concentrate mix was offered ad libitum in SL and FR diets but was kept isoenergetic to the FR diet in the SLR diet. Bulls were weighed every $15 \mathrm{~d}$. Feed intake was measured daily. Carcass composition was assessed for all animals slaughtered at $699 \pm 65 \mathrm{~kg} \mathrm{BW}$. Meat nutritional quality traits (e.g., fat content and fatty acid composition focusing on $n-6$ and $n-3$ polyunsaturated fatty acids) were measured on the longissimus thoracis, rectus abdominis, and semitendinosus muscles.
\end{abstract}

Metabolic enzyme activity (phosphofructokinase, lactate dehydrogenase, and cytochrome-c oxidase) was measured on these muscles and on liver. The SL diet bulls had greater fattening performance, BW gain $(P=$ $0.006)$, and efficiency for growth $(P=0.025)$ at an energy intake similar to that of FR diet bulls. They also had heavier carcasses with a greater proportion of fat. However, liver samples showed no difference in specific metabolic activity. Compared to bulls fed the SL diet, bulls fed SLR consumed 15\% less energy and had lower BW gain $(P<0.001)$ but were slightly more efficient for growth $(P=0.010)$. They had lower carcass weight but a greater muscle-to-fat ratio. Compared to bulls fed the FR diet, SLR bulls had lower than planned $\mathrm{NE}_{\mathrm{g}}$ intake and lower $\mathrm{BW}$ gain but did not have differences in body composition. Compared to the FR diet, the SL diet led to a greater omega-3 fatty acid content because of a greater supply of dietary linoleic acid, especially in lean muscle.

Key words: bull fattening, carcass composition, energy, fatty acids, metabolism doi:10.2527/jas2014-7845

\section{INTRODUCTION}

\footnotetext{
${ }^{1}$ This experiment was funded by McKey Food Services (Fleuryles-Aubrais, France), Valorex (Combourtillé, France), and the regional council of the French Centre region. The authors greatly thank the staff of INRA unit UE232 for animal care and data collection and the staff of INRA unit UMR1213 experimental farm and slaughterhouse for animal transport and care, slaughter, and data collection. The authors give special thanks to Pierre Nozière for valuable advice.

2Present address: INRA, UMR1213 Herbivores, F-63122 Saint-Genès Champanelle, France.

${ }^{3}$ Corresponding author: marie-madeleine.richard@clermont.inra.fr Received March 17, 2014.

Accepted October 21, 2014.
}

Bulls are often fattened using starch-rich diets to yield high BW gain (BWG). However, cereal-fed ruminants are in competition with humans for use of feed resources, and high intakes of starch-rich diets can trigger ruminal acidosis. An alternative strategy may be to feed fiber-rich diets, which give comparable performance if intake is high enough to compensate for the lower energy value, as argued by Bradford and Mullins (2012) for dairy cattle. Alternatively, lipids present the greatest energy value among all feed ingredients and may 
also help to limit acidosis. Several trials have studied the effect of concentrate type on fattening performance, but very few analyzed this effect while dissociating the impact of energy intake from the type of energy source (Mueller et al., 2011). Type of concentrate energy may modify dietary digestive and metabolic efficiency as well as absorbed nutrient profile. As a consequence, type of concentrate may lead to significant differences in performance, muscle metabolism, and carcass composition (Hocquette et al., 2007). Consumers often see beef negatively as high in fats rich in SFA and trans-MUFA, which are considered risk factors for human health (Riediger et al., 2009). A moderate incorporation of linseed in the diet can increase the content of beneficial $n-3$ PUFA and reduce SFA in beef (Doreau et al., 2011).

The objectives of this study were 1) to determine the fattening performance and carcass responses of bulls fed high-concentrate diets rich either in a mixture of starch plus linseed or in fibrous by-products while separating the effects of the source and level of energy intake, 2) to relate differences in performance to metabolic activities measured in the liver and 2 muscles at slaughter, and 3) to study the effects of including feeds rich in omega-3 fatty acids (FA) on FA composition in 3 muscles.

\section{MATERIALS AND METHODS}

\section{Animals, Experimental Design, and Dietary Treatments}

In total, 140 Charolais bulls were used from weaning in a fattening trial repeated over 2 successive years, with 70 bulls of the same genetic origin in each trial. The experiment took place at the INRA experimental farm in Bourges, France. At weaning, the animals averaged $239 \pm 9 \mathrm{~d}$ old and weighed $319 \pm 27 \mathrm{~kg}$. They were assigned to 10 groups of 7 animals of similar initial average BW each year. Each group was housed in a separate pen. Pens were contiguous in the same shed $\left(7 \mathrm{~m}^{2}\right.$ per bull) and were bedded with barley straw. Three diets composed of $81 \%$ to $87 \%$ concentrate were compared: FR (based on a fiber-rich concentrate, offered ad libitum), SL (based on a starch- and lipid-rich concentrate, offered ad libitum), and SLR (based on the same concentrate as SL but offered in restricted amounts to match the $\mathrm{NE}_{\mathrm{g}}$ intake $\left[\mathbf{N E}_{\mathbf{g}} \mathbf{I}\right]$ of the FR group). The number of pens receiving the FR, SL, and SLR diets was 4, 4, and 2 each year, respectively. After $3 \mathrm{wk}$ of adaptation to experimental treatments and progressive achievement of ad libitum feeding for FR and SL diets, bulls were fattened for a minimum of $228 \mathrm{~d}$ and were slaughtered at the same average age of 17 to $18 \mathrm{mo}$, as usually done for this type of animal. Experimental procedures were conducted in ac-
Table 1. Ingredient, measured chemical composition, and tabulated energy content of the experimental diets ${ }^{1}$

\begin{tabular}{lccc}
\hline \hline & \multicolumn{3}{c}{ Diet $^{2}$} \\
\cline { 2 - 4 } Item & $\mathrm{FR}$ & $\mathrm{SL}^{3}$ & $\mathrm{SLR}^{3}$ \\
\hline Straw-to-concentrate ratio (DM basis) & $12: 88$ & $13: 87$ & $18: 82$ \\
Chemical composition, g/kg DM & & & \\
OM & 806 & 828 & 829 \\
NDF & 406 & 249 & 269 \\
ADF & 227 & 140 & 154 \\
Starch & 70 & 297 & 282 \\
Crude protein & 145 & 179 & 171 \\
Ether extract & 25 & 41 & 39 \\
GE, MJ/kg DM & 18.9 & 19.7 & 19.6 \\
NE, ${ }^{4} \mathrm{MJ} / \mathrm{kg}$ DM & 6.05 & 7.32 & 7.04 \\
\hline
\end{tabular}

${ }^{1} \mathrm{FR}$ : diet composed of $88 \%$ concentrate rich in fiber and $12 \%$ straw, SL: diet composed of $87 \%$ concentrate rich in starch and lipids and $13 \%$ straw, SLR: diet composed of $83 \%$ concentrate rich in starch and lipids and $17 \%$ straw.

${ }^{2}$ Ingredient composition of the concentrate ( $\left.\mathrm{g} / \mathrm{kg} \mathrm{DM}\right)$ : dehydrated alfalfa, 224; wheat bran, 219; cereal middlings, 184; dehydrated beet pulp, 212; rapeseed meal, 35; barley, 25; palm kernel meal, 40; molasses, 30; mineral-vitamin premix, 8; magnesium oxide, 10; dicalcium phosphate, 6; sodium chloride, 6 .

${ }^{3}$ Ingredient composition of the concentrate $(\mathrm{g} / \mathrm{kg} \mathrm{DM})$ : maize, 280 barley, 98; oats, 86; maize bran, 30; extruded mixture (50\% linseed, $30 \%$ wheat bran, $20 \%$ sunflower meal), 120; soybean meal, 20; dehydrated beet pulp, 60; rapeseed meal, 214; molasses, 70; urea, 4; mineral-vitamin premix, 5; calcium carbonate, 10; sodium bicarbonate, 3 .

${ }^{4}$ Calculated from feed tables (INRA, 2007).

cordance with French Ministry of Agriculture guidelines on animal welfare and use for experimental purposes (http://www2.vet-lyon.fr/ens/expa/acc_regl.html).

The FR diet concentrate consisted mainly of cereal by-products, dehydrated alfalfa, and dehydrated beet pulp. The SL and SLR diet concentrate consisted of cereals and an extruded mixture containing $500 \mathrm{~g} / \mathrm{kg}$ linseed (Valorex, Combourtillé, France) to achieve a theoretical level of $12 \mathrm{~g}$ of omega-3 FA from linseed per kilogram of DM of concentrate. In all 3 dietary treatments, bulls were offered barley straw ad libitum in a rack in each pen. This ad libitum distribution was expected to result in a greater proportion of straw in the SLR diet because of the feed restriction. Diet ingredients and chemical composition are reported in Table 1. Net energy for gain, estimated from diet composition according to INRA (2007) feed tables, was 6.05, 7.32, and 7.04 MJ/kg DM for the FR, SL, and SLR diets. Concentrates had the same ratio of $\mathrm{NE}_{\mathrm{g}}$ to MP expressed in INRA (2007) units, equal to $16 \mathrm{~g} \mathrm{MP} / \mathrm{MJ} \mathrm{NE}$. Diets were formulated according to recommendations (INRA, 2007) to meet $\mathrm{NE}_{\mathrm{g}}$ and $\mathrm{MP}$ requirements needed for maintenance and theoretical BW gain (1,500 g/d for FR and 1,800 g/d for SL). The theoretical BWG for the FR diet corresponds to previously observed gain with the same diet distributed ad libitum to Charolais bulls. It was assumed that the SL diet distributed ad libitum would be consumed at similar DMI as the FR diet, leading to greater expected gains. 
Anion-cation balance was 134 and $119 \mathrm{meq} / \mathrm{kg}$ DM for FR and SL concentrates, respectively. Bulls fed the SLR diet were offered restricted amounts of concentrate mixture to provide the same average NE and MP per unit metabolic BW $\left(\mathrm{BW}^{0.75}\right)$ as those of FR diet animals for similar theoretical BWG. The amount of concentrate distributed to the SLR group was thus readjusted every $2 \mathrm{wk}$ on the basis of the average NE intake per kilogram of BW of the FR group over the preceding 2 wk. A commercial mineral-vitamin premix was added to the concentrates at a level of 8 and $5 \mathrm{~g} / \mathrm{kg}$ concentrate DM for FR and SL diets, respectively. Both concentrates were produced as pellets after the ingredients were ground (Jacques Coeur, Joigny, France). Concentrates were distributed once daily at $0800 \mathrm{~h}$ using an automatic feeding system (Calan system, Drafhandel Decuyper, Brussels, Belgium). Allowances were adjusted every $2 \mathrm{~d}$ to ensure $10 \%$ refusals in the ad libitum-fed groups (FR and SL). Fresh water was available at all times in each pen.

\section{Measurements and Samplings during Fattening and at Slaughter}

Each bull was equipped with an electronic transponder (Dairy gate, EFEI, Villeroy, France) around its neck that opened its specific feeder, and individual concentrate intake was recorded by measuring offered amounts every day and refusals every $2 \mathrm{~d}$. Straw intake was measured for each pen by weighing each bale. Individual straw intake was calculated from the average intake for the pen, assuming that bedding straw intake was negligible. Each year, 3 feed samples were composed from 8 weekly subsamples taken over 2-mo periods for chemical analyses, that is, a total of 6 samples for each feed. Feeds were ashed at $550^{\circ} \mathrm{C}$ for $6 \mathrm{~h}$ for $\mathrm{OM}$ determination: nitrogen was determined by the Kjeldahl procedure (AOAC, 1990); NDF and ADF were determined according to Van Soest et al. (1991); starch was determined by spectrophotometry after enzymatic analysis (Faisant et al., 1995); GE was measured by isoperibolic calorimetry (C200 model, IKA, Staufen, Germany), ether extract (EE) was measured using petroleum extract (AOAC, 1990). Body weight was determined every $14 \mathrm{~d}$ and at fixed hours during the whole fattening period.

At the end of fattening, bulls were transported by truck to INRA's experimental slaughterhouse $200 \mathrm{~km}$ away (Clermont-Ferrand, France). On arrival at about $1500 \mathrm{~h}$, the bulls were housed in a straw-bedded lairage pen and were offered their usual diet with water at disposal. Feed was removed at $2000 \mathrm{~h}$ for an overnight fast. Bulls were slaughtered at the same average age under standard conditions in the same experimental slaughterhouse. Carcasses were processed by removal of the head, tail, feet, and abdominal and thoracic viscera. Hot carcass, internal fat (i.e., peritoneal, omental, mesenteric, and kidney fat), and splanchnic organ weights were recorded. Carcasses were chilled and stored at $4^{\circ} \mathrm{C}$ until 24 $\mathrm{h}$ postmortem. The sixth rib was excised and dissected to estimate carcass weights of bone, muscle, and fat (in $\mathrm{kg}$ ) according to the equations proposed by Robelin and Geay (1975) for Charolais bulls.

\section{Preparation of Tissue Samples}

Liver samples ( $\sim 50 \mathrm{~g})$ were taken 35 to $40 \mathrm{~min}$ postmortem, cut into small pieces (5 to $10 \mathrm{~g}$ ), and frozen in liquid nitrogen. Samples from rectus abdominis (RA), longissimus thoracis (LT), and semitendinosus (ST) muscles (120 to $150 \mathrm{~g}$ ) were taken within $30 \mathrm{~min}$ postmortem, cut into small pieces (5 to $10 \mathrm{~g}$ ), and frozen in liquid nitrogen for measurement of enzyme activities. Samples of the same muscles were taken $24 \mathrm{~h}$ postmortem for muscle lipid and FA analysis. All samples were ground in liquid nitrogen in a M20 mill (IKA-Werke, Staufen, Germany) to produce a fine homogeneous powder, then stored at $-80^{\circ} \mathrm{C}$ for lipid and FA analysis.

\section{Metabolic Enzyme Activity}

Metabolic enzyme activities characterizing glycolytic (phosphofructokinase [PFK, EC 2.7.1.11] and lactate dehydrogenase [LDH, EC 1.1.1.27]) or oxidative (cytochrome c oxidase (COX, EC 1.9.3.1]) metabolism were determined spectrophotometrically on liver and muscle samples from only FR and SL bulls, as described by Piot et al. (1998) and Jurie et al. (2006). Tissue protein content was determined spectrophotometrically with BSA as the standard according to Bradford (1976). All enzyme activities were measured in duplicate at $25^{\circ} \mathrm{C}$ and are expressed in micromoles of molecules converted per minute and per gram of wet muscle or per gram of tissue protein.

\section{Muscle Lipid and Fatty Acid Analysis}

Muscle DM was assayed gravimetrically after drying at $80^{\circ} \mathrm{C}$ for $48 \mathrm{~h}$. Total lipids of muscle samples were extracted by grinding $6 \mathrm{~g}$ of muscle powder with 2:1 chloroform-methanol (vol/vol) according to Folch et al. (1957) and then were assayed gravimetrically. Long-chain FA (LCFA) of muscle total lipids were extracted and transmethylated at room temperature for $2 \times 20$ min with sodium methylate $(1 M)$ in methanol followed by boron trifluoride in methanol $(14 \%$, vol/ vol) according to Glass (1971).

Long-chain fatty acid analysis was performed by gas-liquid chromatography on a Peri 2100-model chromatograph (Perichrom, Saulx-les-Chartreux, France) fitted with a CP-Sil 88 glass capillary column (Varian, 
Lake Forest, CA; length: 100 m; i.d.: $0.25 \mathrm{~mm}$ ) with $\mathrm{H}_{2}$ as the carrier gas under conditions described by Scislowski et al. (2005). Total LCFA were quantified using C19:0 as the internal standard. Identification and calculation of the response coefficient of each individual LCFA were achieved using a quantitative mix of C4 to C24 FA methyl esters (Supelco, Bellefonte, PA).

\section{Digestibility Trial}

At the end of the experiment, the digestibility of the FR and SL diets was measured using 6 dry dairy cows (initial BW $643 \pm 52 \mathrm{~kg}$ ) because our facilities were not equipped for separating urine and feces in bulls. Cows received the 2 diets for two 3 -wk periods in a crossover design. Cows were tethered and kept in individual pens with clean, fresh water and mineral blocks available at all times. A 2-wk diet adaptation period was followed by a 6-d fecal collection period. Diet composition was $13 \%$ barley straw and $87 \%$ of either the FR or SL concentrate. Feeds were the same as those given to bulls during fattening. Cows were fed in restricted amounts to keep expected NE intakes the same between diets. Straw and concentrate were given in 3 equal parts at 0900, 1100, and $1600 \mathrm{~h}$. Fecal contamination by urine was avoided thanks to a urine collector attached to the vulva of the cow. Representative feed samples were taken, and the total feces of each animal was pooled to 1 sample per animal. An aliquot of feed and feces samples was dried at $103^{\circ} \mathrm{C}$ for $\mathrm{DM}$ determination. Another aliquot was dried at $60^{\circ} \mathrm{C}$ for $72 \mathrm{~h}$ and then ground through an 0.8 $\mathrm{mm}$ screen before chemical analysis. Crude protein, ash, $\mathrm{NDF}, \mathrm{ADF}$, and GE were determined according to the above-mentioned methods. The NE content of diets was calculated from digestible energy according to equations proposed by INRA (2007). It was assumed that the NE value determined in dry cows applied to fattening bulls.

\section{Calculations and Statistical Analysis}

Total $\mathrm{NE}_{\mathrm{g}} \mathrm{I}$ in the 3 dietary treatments was calculated from the results of the digestibility trial and not from the feed table (INRA, 2007) values. The feed efficiency during a given period was estimated by the ratio of BWG to $\mathrm{NE}_{\mathrm{g}} \mathrm{I}$ during that period. Mean $\mathrm{NE}_{\mathrm{g}} \mathrm{I}, \mathrm{BWG}$, and feed efficiency were calculated during 4 fattening periods $(0$ to $56 \mathrm{~d}, 56$ to $126 \mathrm{~d}, 126$ to $196 \mathrm{~d}$, and 0 to $196 \mathrm{~d}$ ). The 0 to $196 \mathrm{~d}$ period started at the end of the adaptation period and finished at the first slaughter, where all the bulls were present. Muscle and fat gain efficiencies were calculated from the whole fattening period as the ratios of carcass muscle or fat mass to $\mathrm{NE}_{\mathrm{g}}$ or digestible $\mathrm{CP}$ intakes. Eleven bulls were removed from the experiment due to 3 accidental causes and 8 deaths diagnosed as enterotoxemia
Table 2. Feed intake and digestibility of the experimental diets measured in dry cows

\begin{tabular}{|c|c|c|c|c|}
\hline \multirow[b]{2}{*}{ Item } & \multicolumn{2}{|c|}{$\operatorname{Diet}^{1}$} & \multirow[b]{2}{*}{ SEM } & \multirow{2}{*}{$\begin{array}{c}\text { Diet } P \text { - } \\
\text { value }\end{array}$} \\
\hline & FR & SL & & \\
\hline Feed intake, kg DM/d & 9.86 & 7.81 & 0.011 & $<0.001$ \\
\hline \multicolumn{5}{|l|}{ Digestibility, \% } \\
\hline DM & 71.5 & 75.9 & 0.88 & $<0.001$ \\
\hline OM & 69.7 & 75.2 & 0.92 & $<0.001$ \\
\hline NDF & 66.0 & 48.4 & 1.65 & $<0.001$ \\
\hline $\mathrm{ADF}$ & 57.7 & 44.1 & 1.73 & $<0.001$ \\
\hline $\mathrm{CP}$ & 60.5 & 79.5 & 1.12 & $<0.001$ \\
\hline GE & 71.0 & 77.5 & 0.93 & $<0.001$ \\
\hline
\end{tabular}

${ }^{1} \mathrm{FR}$ : diet composed of $88 \%$ concentrate rich in fiber and $12 \%$ straw, SL: diet composed of $87 \%$ concentrate rich in starch and lipids and $13 \%$ straw.

( $n=4,2$, and 2 for the SL, SLR, and FR diets, respectively). Fattening data analysis ultimately dealt with 129 bulls, and carcass data analysis dealt with 123 bulls.

Analysis of variance was run using the MIXED procedure of SAS (SAS Inst. Inc., Cary, NC). For digestibility data, the model included diet and period and their interaction as fixed effects. For intake, growth, and carcass data, the following statistical analysis was chosen to take into account the unbalanced number of pens allocated to each of the 3 diets. Thus, the effect of the 20 pens was considered as the only fixed effect. These pen effects were appropriately combined to estimate diet effects using the "estimate" option of the MIXED procedure. This same "estimate" option was also used to calculate differences between 2 diets. The "contrast" option was ultimately used to test the significance of the diet effect combining 2 of the 3 contrasts among the above diet estimates. For data measured on muscles (lipid and FA composition and enzymatic data), the model included muscle, diet, and their interaction. Muscle was considered to be repeated on the same animal. For data measured on the liver (enzymatic data), diet was the only fixed effect. For all the data measured on bulls, diet means were compared by orthogonal contrasts: FR vs. SL, FR vs. SLR, and SL vs. SLR. Significant interactions were calculated using Student's $t$ test to identify muscle differences and individual treatment differences. Significance was considered when $P \leq 0.05$.

\section{RESULTS}

\section{Diet Digestibility and Energy Value}

The apparent total tract digestibility of the OM was $5.5 \%$ units lower $(P<0.001)$ for cows consuming the FR diet than for cows fed the SL diet (Table 2). SL diet digestibility was lower than expected, as discussed further below. For the FR diet, NDF and ADF digestibility was $17.6 \%$ units greater $(P<0.001)$ than 
Table 3. Feed intake, growth performance, and feed efficiency ratio for bulls offered the experimental diets during 196-d fattening

\begin{tabular}{|c|c|c|c|c|c|c|c|c|}
\hline \multirow[b]{2}{*}{ Item } & \multicolumn{3}{|c|}{$\operatorname{Diet}^{1}$} & \multirow[b]{2}{*}{$\mathrm{SEM}^{2}$} & \multirow{2}{*}{$\begin{array}{c}\text { Diet } \\
P \text {-value }\end{array}$} & \multicolumn{3}{|c|}{ Contrast } \\
\hline & FR & $\mathrm{SL}$ & SLR & & & FR vs. SL & FR vs. SLR & SL vs. SLR \\
\hline Number of animals & 53 & 50 & 26 & & & & & \\
\hline Initial BW, kg & 339 & 337 & 341 & 5.6 & 0.824 & 0.723 & 0.909 & 0.541 \\
\hline Final BW, kg & 649 & 666 & 639 & 9.6 & 0.168 & 0.083 & 0.483 & 0.159 \\
\hline \multicolumn{9}{|c|}{ Feed intake, $\mathrm{kg} \mathrm{DM} / \mathrm{d}$} \\
\hline d 0 to 56 & 8.08 & 7.52 & 5.93 & 0.173 & $<0.001$ & 0.002 & $<0.001$ & $<0.001$ \\
\hline d 56 to 126 & 10.94 & 9.49 & 8.68 & 0.234 & $<0.001$ & $<0.001$ & $<0.001$ & $<0.001$ \\
\hline d 126 to 196 & 11.79 & 10.61 & 9.64 & 0.234 & $<0.001$ & $<0.001$ & $<0.001$ & $<0.001$ \\
\hline d 0 to 196 & 10.31 & 9.24 & 8.16 & 0.185 & $<0.001$ & $<0.001$ & $<0.001$ & $<0.001$ \\
\hline \multicolumn{9}{|l|}{$\mathrm{NE}_{\mathrm{g}}$ intake, $\mathrm{MJ} / \mathrm{d}^{3}$} \\
\hline d 0 to 56 & 53.81 & 57.01 & 44.00 & 1.251 & $<0.001$ & 0.013 & $<0.001$ & $<0.001$ \\
\hline d 56 to 126 & 72.81 & 71.88 & 63.08 & 1.706 & $<0.001$ & 0.590 & 0.001 & $<0.001$ \\
\hline d 126 to 196 & 78.47 & 80.48 & 70.16 & 1.663 & $<0.001$ & 0.234 & $<0.001$ & $<0.001$ \\
\hline d 0 to 196 & 68.68 & 70.03 & 59.46 & 1.333 & $<0.001$ & 0.320 & $<0.001$ & $<0.001$ \\
\hline $\mathrm{CP}$ intake, $\mathrm{kg} / \mathrm{d}$ & 1.50 & 1.65 & 1.39 & 0.031 & $<0.001$ & $<0.001$ & 0.023 & $<0.001$ \\
\hline \multicolumn{9}{|l|}{ BW gain, g/d } \\
\hline d 0 to 56 & 1,470 & 1,537 & 1,289 & 53.7 & $<0.001$ & 0.220 & 0.020 & $<0.001$ \\
\hline d 56 to 126 & 1,784 & 1,786 & 1,796 & 47.8 & 0.812 & 0.958 & 0.866 & 0.575 \\
\hline d 126 to 196 & 1,478 & 1,692 & 1,290 & 51.4 & $<0.001$ & $<0.001$ & 0.012 & $<0.001$ \\
\hline d 0 to 196 & 1,585 & 1,682 & 1,471 & 33.8 & $<0.001$ & 0.006 & 0.020 & $<0.001$ \\
\hline \multicolumn{9}{|c|}{ Feed efficiency, $g$ BW gain/MJ NE } \\
\hline d 0 to 56 & $27.4^{\circ}$ & 26.9 & 29.3 & 0.78 & 0.089 & 0.535 & 0.089 & 0.030 \\
\hline d 56 to 126 & 24.6 & 25.1 & 28.6 & 0.69 & $<0.001$ & 0.435 & $<0.001$ & $<0.001$ \\
\hline d 126 to 196 & 18.8 & 21.1 & 18.4 & 0.63 & 0.003 & $<0.001$ & 0.669 & 0.071 \\
\hline d 0 to 196 & 23.1 & 24.1 & 24.9 & 0.44 & $<0.001$ & 0.025 & 0.006 & 0.010 \\
\hline
\end{tabular}

${ }^{1}$ FR: diet composed of $88 \%$ concentrate rich in fiber and $12 \%$ straw, SL: diet composed of $87 \%$ concentrate rich in starch and lipids and $13 \%$ straw, SLR: diet composed of $83 \%$ concentrate rich in starch and lipids and $17 \%$ straw.

${ }^{2}$ SEM was calculated with $n=26$.

${ }^{3}$ Net energy for gain measured from digestibility data.

for the SL diet, whereas CP digestibility was $19.0 \%$ units lower. Gross energy digestibility was $6.5 \%$ units greater for the SL diet than for the FR diet $(P<0.001)$.

From these results, $\mathrm{NE}_{\mathrm{g}}$ was calculated as 6.67 and $7.59 \mathrm{MJ} / \mathrm{kg} \mathrm{DM}$ for the FR and SL diets, respectively. For the SLR diet, $\mathrm{NE}_{\mathrm{g}}$ was recalculated as $7.30 \mathrm{MJ} / \mathrm{kg}$ $\mathrm{DM}$ after taking into account the greater percentage of straw in the diet (18\% instead of $13 \%$ for SL), and the energy digestibility of barley straw was taken as $40 \%$ (INRA, 2007). These figures were used for subsequent calculations of NE intake and feed efficiency.

\section{Intake, Growth Performance, and Feed Efficiency}

Effect of Type of Energy in Ad Libitum-Fed Bulls (FR vs. SL). Net energy intake did not differ between diets over the whole fattening period, although it was greater $(P=0.013)$ for SL bull than for FR bulls during the 0 to $56 \mathrm{~d}$ period (Table 3 ). The average BWG of bulls offered the SL diet was $6 \%$ greater $(P=$ 0.006) than that of bulls fed the FR diet over $196 \mathrm{~d}$ of fattening, mostly because of strong gains in the last
$70 \mathrm{~d}$ of fattening. Feed efficiency was greater with the SL diet than with the FR diet over the whole fattening period $(P=0.025)$. This difference stemmed from a strong difference in the 126- to 196-d period, where feed efficiency was $11.9 \%$ greater with the SL diet than with the FR diet $(P<0.001)$.

Effect of Intake Level (SL vs. SLR). Bulls fed the SLR diet consumed a greater proportion of straw than bulls fed SL diet (18\% vs. 13\%). Bulls fed the SLR diet consumed daily $1.1 \mathrm{~kg} \mathrm{DM}$ less $(P<0.001)$ than bulls fed the SL diet, and $\mathrm{NE}_{\mathrm{g}} \mathrm{I}$ was consistently around $15 \%$ lower over the whole experimental period $(P<0.001)$ for SLR vs. SL bulls; SLR-fed bulls thus had a $12.5 \%$ lower BWG $(P<0.001)$ than SL-fed bulls. The efficiency for growth was greater for the SLR diet than for the SL diet $(P=0.01)$.

Effect of Type of Energy in Feed-Matched Bulls (FR vs. SLR). Net energy intake by SLR-fed bulls was planned to be similar to that of FR-fed bulls. However, because of a lower difference in digestibility between FR and SL and a greater proportion of straw in DMI, $\mathrm{NE}_{\mathrm{g}} \mathrm{I}$ were not as isoenergetic as planned, with $\mathrm{NE}_{\mathrm{g}} \mathrm{I}$ 
Table 4. Carcass characteristics for bulls offered the experimental diets

\begin{tabular}{|c|c|c|c|c|c|c|c|c|}
\hline \multirow[b]{2}{*}{ Item } & \multicolumn{3}{|c|}{ Diet $^{1}$} & \multirow[b]{2}{*}{$\mathrm{SEM}^{2}$} & \multirow{2}{*}{$\begin{array}{c}\text { Diet } \\
P \text {-value }\end{array}$} & \multicolumn{3}{|c|}{ Contrast } \\
\hline & FR & $\mathrm{SL}$ & SLR & & & FR vs. SL & FR vs. SLR & SL vs. SLR \\
\hline Number of animals & 50 & 47 & 26 & & & & & \\
\hline $\mathrm{BW}$ at slaughter, $\mathrm{kg}$ & 709 & 732 & 687 & 9.7 & 0.002 & 0.039 & 0.130 & $<0.001$ \\
\hline Age at slaughter, d & 540 & 537 & 532 & 1.7 & 0.002 & 0.067 & 0.006 & 0.051 \\
\hline Empty BW, kg & 625 & 661 & 602 & 9.1 & $<0.001$ & $<0.001$ & 0.118 & $<0.001$ \\
\hline $\mathrm{HCW}, \mathrm{kg}$ & 426 & 453 & 414 & 6.7 & $<0.001$ & $<0.001$ & 0.254 & $<0.001$ \\
\hline Cold carcass weight, $\%$ BW & 57.4 & 59.0 & 57.8 & 0.30 & $<0.001$ & $<0.001$ & 0.271 & 0.002 \\
\hline \multicolumn{9}{|l|}{ Carcass composition, ${ }^{3} \%$} \\
\hline Muscle & 71.3 & 69.6 & 71.7 & 0.34 & $<0.001$ & $<0.001$ & 0.922 & $<0.001$ \\
\hline Fat & 14.8 & 17.0 & 14.2 & 0.36 & $<0.001$ & $<0.001$ & 0.446 & $<0.001$ \\
\hline Bone & 14.2 & 13.6 & 14.4 & 0.12 & $<0.001$ & $<0.001$ & 0.136 & $<0.001$ \\
\hline \multicolumn{9}{|l|}{ Carcass composition $^{3}, \mathrm{~kg}$} \\
\hline Muscle & 304 & 315 & 297 & 5.0 & 0.012 & 0.044 & 0.254 & 0.004 \\
\hline Fat & 61.7 & 75.6 & 57.5 & 2.00 & $<0.001$ & $<0.001$ & 0.106 & $<0.001$ \\
\hline Bone & 60.4 & 61.8 & 59.4 & 0.85 & 0.086 & 0.161 & 0.335 & 0.031 \\
\hline Muscle-to-fat ratio & 4.84 & 4.23 & 5.07 & 0.136 & $<0.001$ & $<0.001$ & 0.406 & $<0.001$ \\
\hline Internal fat, $\mathrm{kg}$ & 18.5 & 26.0 & 15.9 & 1.18 & $<0.001$ & $<0.001$ & 0.212 & $<0.001$ \\
\hline \multicolumn{9}{|l|}{ Organ weight, $\mathrm{kg}$} \\
\hline Empty digestive tract & 34.8 & 31.9 & 30.6 & 8.45 & $<0.001$ & $<0.001$ & $<0.001$ & 0.089 \\
\hline Reticulorumen & 13.5 & 11.2 & 10.6 & 0.33 & $<0.001$ & $<0.001$ & $<0.001$ & 0.151 \\
\hline Omasum & 5.22 & 3.84 & 4.06 & 0.201 & $<0.001$ & $<0.001$ & $<0.001$ & 0.391 \\
\hline Abomasum & 2.16 & 2.20 & 1.96 & 0.064 & 0.012 & 0.550 & 0.044 & 0.004 \\
\hline Intestines & 14.0 & 14.7 & 13.9 & 0.28 & 0.042 & 0.029 & 0.476 & 0.036 \\
\hline Liver & 6.53 & 6.69 & 6.35 & 0.137 & 0.156 & 0.292 & 0.413 & 0.056 \\
\hline \multicolumn{9}{|l|}{ Energetic efficiency, g/MJ } \\
\hline Muscle/NE ${ }_{g}$ & 17.48 & 17.82 & 21.59 & 0.343 & $<0.001$ & 0.379 & $<0.001$ & $<0.001$ \\
\hline $\mathrm{Fat} / \mathrm{NE}_{\mathrm{g}}$ & 3.63 & 4.29 & 4.32 & 0.089 & $<0.001$ & $<0.001$ & $<0.001$ & 0.803 \\
\hline \multicolumn{9}{|l|}{ Protein efficiency, $\mathrm{g} / \mathrm{kg}$} \\
\hline Muscle/digestible CP & 1,312 & 940 & 1,086 & 20.2 & $<0.001$ & $<0.001$ & $<0.001$ & $<0.001$ \\
\hline Fat/digestible CP & 273 & 226 & 217 & 5.1 & $<0.001$ & $<0.001$ & $<0.001$ & 0.168 \\
\hline
\end{tabular}

${ }^{1} \mathrm{FR}$ : diet composed of $88 \%$ concentrate rich in fiber and $12 \%$ straw, SL: diet composed of $87 \%$ concentrate rich in starch and lipids and $13 \%$ straw, SLR diet composed of $83 \%$ concentrate rich in starch and lipids and $17 \%$ straw.

${ }^{2}$ SEM was calculated with $n=26$.

${ }^{3}$ Estimated from sixth rib composition obtained by dissection. Fat weight is the sum of internal, subcutaneous and intermuscular fat weights.

ultimately $13 \%$ lower $(P<0.001)$ in the SLR treatment vs. the FR treatment over the whole fattening period (Table 3). Average BWG from 0 to $196 \mathrm{~d}$ of fattening was $7 \%$ lower $(P=0.02)$ with the SLR diet vs. the FR diet. Overall, feed efficiency from 0 to $196 \mathrm{~d}$ was $7.6 \%$ greater for the SLR diet than for the FR $\operatorname{diet}(P=0.006)$.

\section{Slaughter Performance, Carcass Traits, and Efficiency of Muscle and Fat Gain}

Effect of Type of Energy in Ad Libitum-Fed Bulls (FR vs. SL). Consistent with the greater average $\mathrm{NE}_{\mathrm{g}}$ and CP intakes, SL bulls had 3\% greater BW $(P=0.039)$ and $6 \%$ greater $\mathrm{HCW}(P<0.001)$ at slaughter than FR bulls (Table 4). The ratio of cold carcass weight to onfarm BW was also greater for SL bulls $(P<0.001)$. Carcass composition showed proportionally more fat and less muscle $(P<0.001)$ for SL bulls than for FR bulls. Muscle-to-bone ratios were similar, with a value of 5 .
Consequently, muscle mass was $11 \mathrm{~kg}$ greater (315 vs. $304 \pm 4.28 \mathrm{~kg} ; P<0.05)$ and carcass fat mass was $14 \mathrm{~kg}$ greater (75.6 vs. $61.7 \pm 1.74 \mathrm{~kg} ; P<0.001)$ in SL bulls than in FR bulls, and fat mass in the fifth quarter was also $7.5 \mathrm{~kg}$ greater $(\mathrm{SEM}=1.18 ; P<0.001)$. The lower forestomach weights (reticulorumen and omasum) in the bulls fed the SL diet $(P<0.001)$ were consistent with their lower DMI. Conversely, intestinal weight was greater in the SL bulls $(P=0.029)$, probably because of their greater intestinal digestion compared with that of FR bulls. Liver weight was unaffected.

The efficiency of $\mathrm{NE}_{\mathrm{g}}$ use for muscle gain was not affected, whereas the efficiency of $\mathrm{NE}_{\mathrm{g}}$ use for fat gain was $18 \%$ greater for the SL diet than for the FR $\operatorname{diet}(P<$ $0.001)$. The efficiency of digestible $C P$ transfer into muscle and fat was reduced $(P<0.001)$ in the bulls fed SL diet. Had digestibility not been accounted for, differences in $\mathrm{N}$ efficiency would have been greatly reduced. 
Effect of Intake Level (SL vs. SLR). Compared with SL bulls, SLR bulls had 6\% lower BW at slaughter $(P<0.001), 8.6 \%$ lower HCW $(P<0.001)$ but with a greater carcass muscle-to-fat ratio (5.07 vs. $4.23 \pm$ $0.11 ; P<0.001$ ), and a similar muscle-to-bone ratio of 5. Consequently, both carcass muscle and fat mass were lower in SLR vs. SL bulls $(P<0.001)$, as was the amount of fat in the fifth quarter (Table 4). Forestomach weight was not significantly affected by the difference in DMI, but abomasal and intestinal weights were significantly lower in SLR vs. SL bulls $(P=0.004$ and $P=0.036$, respectively), and liver weight tended to be lower $(P<0.06)$. Although muscle gain was lower in SLR bulls, efficiencies of $\mathrm{NE}_{\mathrm{g}}$ and digestible $\mathrm{CP}$ use for muscle gain were significantly increased $(P<0.001)$. Efficiency of $\mathrm{NE}_{\mathrm{g}}$ use for fat gain was not different between the 2 diets. Efficiency of digestible CP use for muscle gain was greater for the SLR $\operatorname{diet}(P<0.001)$.

Effect of Energy Source (FR vs. SLR). Despite differences in $\mathrm{NE}_{\mathrm{g}} \mathrm{I}$ and BWG, FR and SLR bulls did not differ in any body composition traits except fat depots, which tended to be lower for the SLR diet (57.5 vs. $61.7 \mathrm{~kg}$ for the SLR and FR bulls; $\mathrm{SEM}=1.74 ; P<$ 0.10 ), and forestomach (reticulorumen, omasum) and abomasum weight, which were greater $(P<0.044)$ for the fiber-rich FR diet than for the SLR diet. Compared with FR bulls, SLR bulls showed more efficient $\mathrm{NE}_{\mathrm{g}}$ use for muscle and fat gain but less efficient digestible $\mathrm{CP}$ use for muscle and fat gain $(P<0.001)$.

\section{Metabolic Enzyme Activity}

Despite differences in feed efficiency between the FR and SL groups just before slaughter (d 126 to 196), the enzymatic activity of the liver (which is one of the most metabolically active organs) did not differ between the 2 groups (Table 5) on the basis of COX activity (representative of mitochondrial activity) and LDH and PFK activities (representative of glycolytic metabolism), whatever the unit of expression of the results (per g of wet muscle or per $g$ of tissue protein).

In muscle, LDH activity was slightly greater for the SL diet compared for the FR diet in both ST $(+2 \%)$ and LT $(+5 \% ; P<0.047)$ muscles when results were expressed per gram of wet tissue, indicating a greater glycolytic metabolism in muscles of animals fed the SL diet (Table 6). However, when results were expressed per gram of muscle protein, the differences lost significance because of a slightly greater protein content, especially in ST muscle $(+3.4 \% ; P=0.071)$ for the SL diet. For all the other measured enzyme activities, we did not find any significant differences between the diets. However, metabolic activity showed differences between the 2 studied muscles, with LT being more
Table 5. LDH, PFK, and COX enzyme activities in liver for bulls offered the FR $(n=22)$ and SL $(n=21)$ $\operatorname{diets}^{1}$

\begin{tabular}{|c|c|c|c|c|}
\hline \multirow[b]{2}{*}{ Item } & \multicolumn{2}{|c|}{ Diet $^{2}$} & \multirow[b]{2}{*}{ SEM } & \multirow{2}{*}{$\begin{array}{c}\text { Diet } \\
P \text {-value }\end{array}$} \\
\hline & FR & SL & & \\
\hline \multicolumn{5}{|c|}{$\overline{\text { Activity, } \mu \mathrm{mol} \cdot \mathrm{min}^{-1} \cdot \mathrm{g} \text { liver }^{-1}}$} \\
\hline LDH & 57.5 & 62.7 & 2.4 & 0.138 \\
\hline PFK & 3.12 & 2.96 & 0.13 & 0.405 \\
\hline $\mathrm{COX}$ & 48.9 & 48.1 & 2.26 & 0.806 \\
\hline \multicolumn{5}{|c|}{ Activity, $\mu \mathrm{mol} \cdot \min ^{-1} \cdot \mathrm{g}$ protein ${ }^{-1}$} \\
\hline LDH & 313 & 334 & 15.0 & 0.324 \\
\hline PFK & 17.0 & 15.8 & 0.78 & 0.297 \\
\hline COX & 265 & 258 & 13.4 & 0.704 \\
\hline Protein, $\mathrm{g} / \mathrm{kg}$ liver & 185 & 189 & 3.4 & 0.503 \\
\hline $\mathrm{COX} / \mathrm{LDH}, \%$ & 86.9 & 77.3 & 4.60 & 0.150 \\
\hline
\end{tabular}

${ }^{1}$ Lactate dehydrogenase (LDH), phosphofructokinase (PFK), and cytochrome c oxidase (COX).

${ }^{2} \mathrm{FR}$ : diet composed of $88 \%$ concentrate rich in fiber and $12 \%$ straw, SL: diet composed of $87 \%$ concentrate rich in starch and lipids and $13 \%$ straw.

oxidative (because of a greater $\mathrm{COX} / \mathrm{LDH}$ ratio) than ST for the FR diet, as expected. Note that this difference was negated in the SL diet, as indicated by a significant muscle $\times$ diet interaction for some variables (especially the $\mathrm{COX} / \mathrm{LDH}$ ratio).

\section{Lipids and Fatty Acids in Muscles}

Total lipids and total FA (g/100 g fresh tissue) and individual FA and FA class (mg/100 $\mathrm{g}$ fresh tissue) contents of LT, RA and ST muscles are given in Table 7. Total lipid contents differed with muscle type and body localization, being 1.6 to 2.0 and 1.4 to 1.6 times greater in LT and RA muscles, respectively, than in ST muscle $(P<0.001)$. Similar variations with muscle type were noted for total FA content, which was 1.9 to 2.3 and 1.7 to 1.9 times greater in LT and RA muscles than in ST muscle, respectively $(P<0.001)$. Total lipid and FA contents were significantly influenced by diets, being greater with the SL diet than with the FR and SLR diets $(P<0.001)$ which had similar lipid and FA contents. A significant $(P<0.001)$ muscle $\times$ diet interaction was found for total lipids but not for total FA (Table 7).

Total SFA muscle content varied with muscle type and diet in patterns similar to those of total lipids and FA (Table 7). Saturated FA were mainly palmitic acid $(16: 0, \approx 22 \%$ of total FA) and stearic acid $(18: 0, \approx 16 \%)$. Total and individual SFA did not differ between the FR and SLR diets but were greater for SL than for the other 2 diets $(P<0.001)$, with significant muscle $\times$ diet interactions ( $P=0.002$ to 0.003 according to FA). The ratio of 16:0 to $18: 0$ was mainly influenced by muscle type, being 10.3, 17.9, and 17.2 lower in LT muscle 
Table 6. LDH, PFK, and COX enzyme activities in longissimus thoracis (LT) and semitendinosus (ST) and muscles $(\mathrm{M})$ for bulls offered the FR $(n=22)$ and SL $(n=21)$ diets (D) ${ }^{1}$

\begin{tabular}{|c|c|c|c|c|c|c|c|c|}
\hline \multirow[b]{3}{*}{ Item } & \multicolumn{4}{|c|}{ Diet and muscle ${ }^{2}$} & \multirow[b]{3}{*}{ SEM } & \multirow{2}{*}{\multicolumn{3}{|c|}{$P$-value }} \\
\hline & \multicolumn{2}{|c|}{ FR } & \multicolumn{2}{|c|}{ SL } & & & & \\
\hline & LT & ST & LT & ST & & $M$ & $\mathrm{D}$ & $\mathrm{M} \times \mathrm{D}$ \\
\hline \multicolumn{9}{|c|}{ Activity, $\mu \mathrm{mol} \cdot \mathrm{min}^{-1} \cdot \mathrm{g} \mathrm{muscle}^{-1}$} \\
\hline LDH & 1,019 & 1,014 & 1,070 & 1,035 & 12.7 & 0.267 & 0.047 & 0.413 \\
\hline PFK & 127 & 108 & 135 & 122 & 5.0 & 0.029 & 0.115 & 0.663 \\
\hline COX & $12.4^{\mathrm{a}}$ & $9.8^{b}$ & $11.5^{\mathrm{a}, \mathrm{b}}$ & $11.3^{\mathrm{a}, \mathrm{b}}$ & 0.38 & 0.015 & 0.663 & 0.032 \\
\hline \multicolumn{9}{|c|}{ Activity, $\mu \mathrm{mol} \cdot \min ^{-1} \cdot \mathrm{g}_{\text {protein }}{ }^{-1}$} \\
\hline LDH & 4,719 & 4,980 & 4,911 & 4,933 & 65.9 & 0.138 & 0.442 & 0.207 \\
\hline PFK & 588 & 529 & 621 & 584 & 24.6 & 0.172 & 0.212 & 0.750 \\
\hline $\operatorname{cox}$ & 57.7 & 48.4 & 52.8 & 53.4 & 1.84 & 0.103 & 0.978 & 0.063 \\
\hline Protein, $\mathrm{g} / \mathrm{kg}$ muscle & 216 & 204 & 218 & 211 & 1.8 & $<0.001$ & 0.071 & 0.334 \\
\hline COX/LDH, \% & $1.23^{\mathrm{a}}$ & $0.97^{\mathrm{b}}$ & $1.08^{\mathrm{a}, \mathrm{b}}$ & $1.09^{\mathrm{a}, \mathrm{b}}$ & 0.038 & 0.030 & 0.814 & 0.016 \\
\hline
\end{tabular}

than in RA and ST muscles from bulls given the FR, SL, and SLR diets, respectively $(P<0.001)$.

Total MUFA, composed of cis and trans isomers, represented $32 \%$ to $42 \%$ of total FA according to the type of muscle and diet considered (Table 7); MUFA deposition was 1.9 to 2.1 and 2.0 to 2.4 times greater in RA and LT muscles than in ST muscle, respectively $(P<$ 0.001), whatever the dietary conditions. Cis-MUFA, which represented $88 \%$ to $93 \%$ of total MUFA, were dominated by oleic acid (18:1n-9 cis, $77 \%$ to $82 \%)$ irrespective of diet and muscle type. As for SFA, muscle deposition of total SFA was significantly $(P<0.001)$ influenced by dietary energy level, being 1.9 to $2.2,1.5$ to 1.8 , and 1.7 to 1.8 times greater for the SL diet than for the 2 other diets for LT, RA, and ST muscles, respectively $(P<0.001)$. Similar diet effects were found for muscle trans-MUFA contents. However, transMUFA contents were 1.7, 1.6, and 1.5 times greater in RA, LT, and ST muscles of bulls given the SLR diet than in those of bulls given the FR $\operatorname{diet}(P=0.010)$. All 18-carbon MUFA isomers were greater in RA and LT than in ST, and most of them were diet dependent (Table 8). The main cis isomers, oleic acid (cis-9 18:1), and cis vaccenic acid (cis-11 18:1) were greater in SL samples than in SLR samples $(P<0.001)$. The coelution of trans-11 (trans vaccenic acid) and trans-10 18:1, which is the major peak of trans-MUFA, is greater for the SL diet than for the SLR $\operatorname{diet}(P=0.038)$ and greater for the SL and SLR diets than for the FR diet $(P<0.01)$.

Total PUFA, composed of $n$ - 6 PUFA, $n-3$ PUFA, and conjugated linoleic acids (CLA, mainly rumenic acid, cis9, trans-11 18:2) varied according to muscle $(P<0.001)$ and $\operatorname{diet}(P<0.001)$ and accounted for $12 \%$ to $16 \%, 12 \%$ to $14 \%$ and $19 \%$ to $24 \%$ of total FA for RA, LT, and ST, respectively, with ST having the lowest total FA content
(Table 7). The $n-6$ PUFA were mainly composed of $18: 2$ $n-6$ (linoleic acid) and 20:4 n-6 (arachidonic acid). In all muscles considered, linoleic acid represented $10.9 \%$ and $9.6 \%$ of total FA in muscles from bulls fed at the lowest energy intakes (FR and SLR diets) but only $6.6 \%$ of total FA in the SL diet. Quantitatively, linoleic acid content was $16 \%$ to $20 \%$ greater in RA and LT muscles than in ST muscle, irrespective of diet $(P<0.001)$, whereas arachidonic acid content was greater in ST than in RA and LT. The $n-3$ PUFA were mainly composed of 18:3n-3 (linolenic acid) as well as 20- and 22-carbon $n$-3 PUFA, mainly represented by 20:5 n-3 (eicosapentaenoic acid, EPA; 2.3 to $7.8 \mathrm{mg} / 100 \mathrm{~g}$ ) and especially $22: 5 n$-3 (docosapentaenoic acid, DPA; 6.9 to $12.3 \mathrm{mg} / 100 \mathrm{~g}$ ) but poor in 22:6n-3 (docosahexaenoic acid, DHA; $<1.3 \mathrm{mg} / 100$ g; Table 7). Muscle linolenic acid, EPA, DPA, and DHA content was, in all 3 muscles, highly and mainly influenced by linseed supplementation, being greater for the SL and SLR diets (rich in linolenic acid) than for the FR $\operatorname{diet}(P<0.001)$. Eicosapentaenoic acid and DPA content was mainly influenced by muscle type, being $47 \%$ to $70 \%$ and $16 \%$ to $23 \%$ greater in ST than in RA and LT, respectively $(P<0.001)$, irrespective of diet. In other respects, CLA content was 1.5 to 1.8 and 2.7 to 3.2 times greater in SL bulls than in FR and SLR bulls, respectively $(P<0.001)$, for all muscles.

The $n-6: n-3$ PUFA ratio and 18:2 $n-6$ to $18: 3 n-3$ ratio differed among muscles and were greater for bulls given the FR diet than for bulls fed the SL and SLR diets $(P<0.001)$. In other respects, PUFA:SFA ratio was 1.7 to 2.0 times greater in ST muscle than in RA and LT muscles $(P<0.001)$, irrespective of diet. 


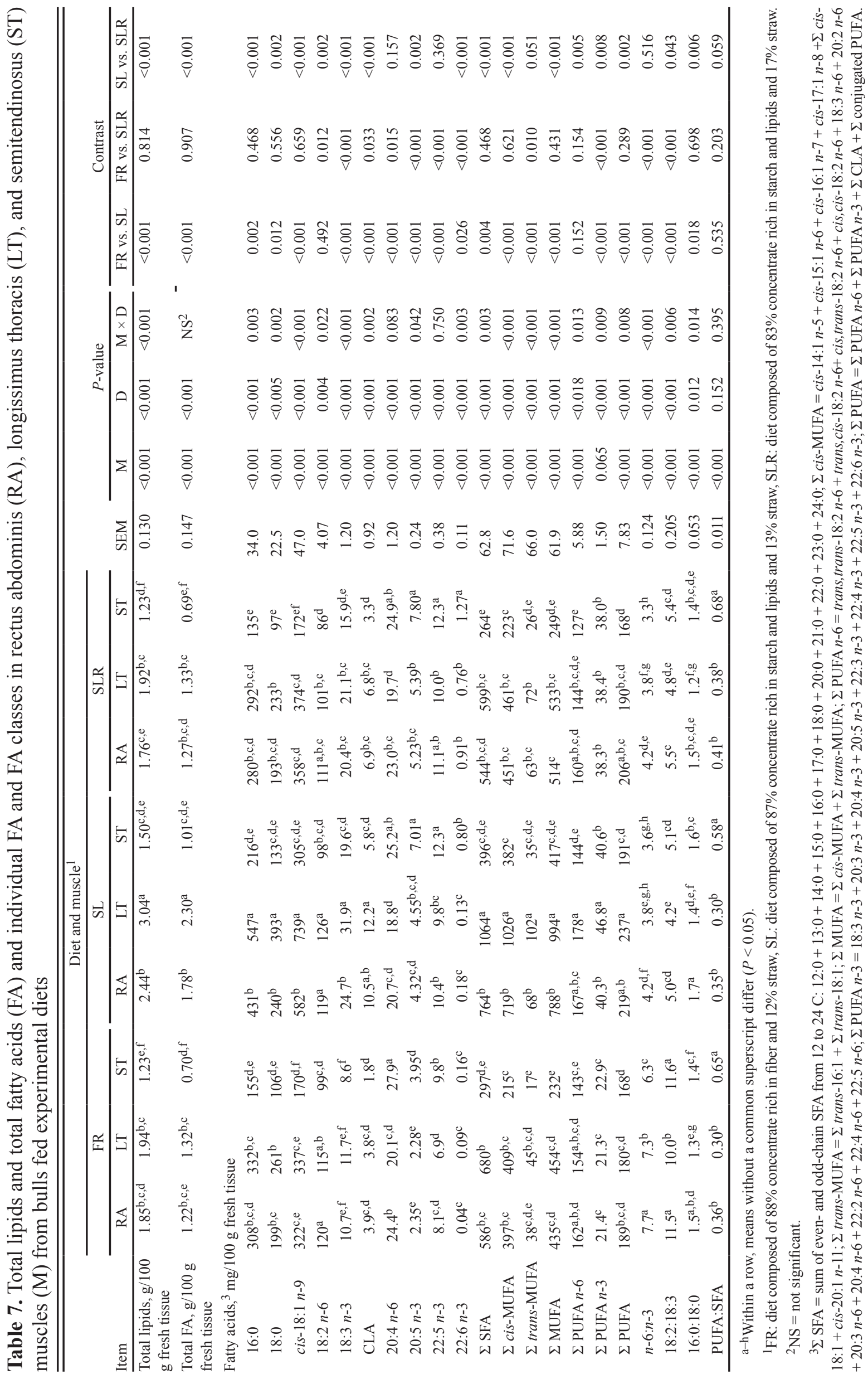




\section{DISCUSSION}

Alternative strategies to feeding high-cereal diets to fattening bulls have to focus not only on achieving high levels of growth but also on using alternative feeds that do not compete with human food, improve feed efficiency, and ensure nutritionally good-quality meat (Hocquette et al., 2007; Doreau et al., 2013). Three strategies were tested here on the basis of 1) using high-concentrate diets to maximize intake, 2) replacing part of the cereals with a fat source to ensure energy density and to limit the risks of acidosis, and 3 ) using highly digestible fiber sources. The effects of energy source were separated from those of intake level. Starch-based diets are known to increase carcass fat at similar metabolizable energy intake (Brennan et al., 1987), but the effect may also depend on the rate of gain (Coleman et al., 1995). Few experiments have studied the impact of energy source in finishing cattle at controlled intakes (Brennan et al., 1987; Bartoň et al., 2007; Costa et al., 2013). The effect of the source and amount of energy has most often been studied in growing cattle, often during winter growing programs, showing little carryover effects on body composition and fat depots over fattening (e.g., Sharman et al., 2013). To our knowledge, there is no published experiment comparing fiber-rich and starch-plus-lipid-rich concentrate diets fed to bulls continuously over the growing and fattening phases and dissociating the effects of energy source from those of intake level.

\section{Nutritional Value of Diets and Ad Libitum Intakes}

Dry cows were used instead of bulls for digestibility measurements. A bias in results cannot be excluded because of differences in age and sex and because cows were fed in restricted amounts. However, the difference may have a low extent, as shown by Dulphy et al. (1990): OM digestibility was $1 \%$ to $3 \%$ units greater in cows than in bulls receiving the same diets. In any case, NE calculations from effective digestibility measurements are likely more accurate than calculations arising from feed tables.

According to the INRA (2007) feeding system, we expected to record approximately a $17 \%$ difference in NE content between FR and SL diets. However, the digestibility trial showed more limited differences, leading to a SL diet energy value that was $12 \%$ lower than expected. This may be due to limited fiber digestion with high-starch diets because of disturbances to the ruminal microbial ecosystem, that is, fewer cellulolytic bacteria and fewer protozoa (Dehority and Orpin, 1997), but it is not likely to be due to fat addition, which was too low to impair ruminal fiber digestion (Doreau et al., 2009). 
The digestibility of the SLR diet was further reduced because of a greater proportion of straw in the diet (18\% vs. $13 \%$ ), but the greater straw intake contributed to limiting the difference in $\mathrm{NE}_{\mathrm{g}} \mathrm{I}$ between the SLR and FR diets. Consequently, when dietary NE was calculated from the results of the digestibility trial, $\mathrm{NE}_{\mathrm{g}} \mathrm{I}$ was lower in SLR bulls than in FR bulls, so the objective of the design was not reached. A time course adaptation of the ruminal microbial ecosystem may be assumed for bulls fed the SL and SLR diets, which may lead to a greater energy value for these diets after a few months of fattening, but that process was impossible to quantify here.

Ad libitum intake was the first evaluation criterion of the diets. Despite the fact that SL diet intake may have been limited by possible digestive discomfort resulting from high-cereal diets (Mialon et al., 2008) and by a more friable consistency, ad libitum intakes were high. Conversely, bulls fed the FR diet did not consume enough feed to achieve their growth potential. This result is especially surprising because the bulls were used to consuming the FR concentrate before weaning from as early as 8 wk of age, and the role of learning on food preferences is well known (Provenza, 1995). The FR diet probably resulted in a greater ruminal bulk, as suggested by a greater reticulorumen weight, but a physical limitation of intake at the ruminal level is unlikely as the diet was offered as pellets with high digestibility. We can posit that SL concentrate is more palatable than FR concentrate, independent of postingestive consequences (FavreauPeigné et al., 2013). In a feedlot trial comparing highfiber and high-starch concentrates in 45\% forage diets, Mueller et al. (2011) observed a greater DMI for highfiber diets but similar ME intake between diets and thus a metabolic regulation of intake.

Taken together, the intake differences in $\mathrm{NE}_{\mathrm{g}}$ and digestible CP were lower than expected between FR bulls and SL or SLR bulls. Actual $\mathrm{NE}_{\mathrm{g}}$ I did not differ between the FR and SL diets but was lower in the SLR diet than in the FR (by 13\%) and SL (by 15\%) diets. These treatment differences will thus be discussed together.

\section{Growth, Slaughter Characteristics, and Efficiency}

The intake level at a given diet composition (SL vs. SLR) affected growth rates and body and carcass composition, as expected (Hoch and Agabriel, 2004). Body and carcass weights were decreased at restricted intakes, with leaner carcasses and lower visceral weights (abomasum + intestine + liver). This result is consistent with the results of Sami et al. (2004) for Simmental bulls that were finished on corn silageconcentrate diets and slaughtered at 18 to 19 mo and with knowledge of intake level effects on visceral mass
(Ortigues and Doreau, 1995). The covariance adjustment for differences in fasted BW (data not shown) indicated that differences in visceral mass were due to changes in BW. However, differences in body composition were not due to changes in weight gain but to an increased fat-to-protein gain ratio in the SL diet. The greater dressing percentage with the SL diet is not due to differences in splanchnic organ weight, which tends to be greater for SL diets. Feed efficiency $\left(\mathrm{BWG} / \mathrm{NE}_{\mathrm{g}}\right.$ ) was significantly improved at restricted intakes, along with the efficiency of digestible $\mathrm{N}$ depot as muscle, whereas the efficiency of $\mathrm{NE}_{\mathrm{g}}$ use for fat depot was not significantly modified, which is in line with Geay et al. (1987). On these bases, performance comparisons of the FR bulls vs. the SL and SLR bulls should be able to dissociate the impact of the intake level from the impact of the intake composition.

First, the increased fatness of SL (vs. FR) bulls may have stemmed from cumulating factors over the long feeding period (approximately $300 \mathrm{~d}$ ). The numerically greater energy intake for the SL diet than for the FR diet resulted in a greater weight gain, which was more marked after $126 \mathrm{~d}$ of fattening, with a difference of $14.5 \%$. Bulls fed the SL diet may have needed a fairly long period of adaptation to express changes in fat deposition. Break points are known to exist before fat, particularly in intramuscular fat depots, increases (Carter et al., 2002). Charolais bulls might need to have already achieved most of their growth to efficiently use this starch- and lipids-rich diet and increase their intramuscular fat contents, as was seen in SL muscles.

Strict effects of diet composition could be identified. The most striking differences, interpreted as being due to diet composition, were noted for the proportion of muscle in the carcass and the greater efficiency of digestible $\mathrm{N}$ use for muscle depot. Muscle-to-fat ratio was greater for FR vs. SL bulls (4.9 vs. 4.2) at similar muscle-to-bone ratio. This diet composition effect was confirmed after covariance adjusting tissue gain for differences in empty BW (data not shown). Starch supply likely enhances fat gain. At similar metabolizable energy intake, Mueller et al. (2011) did not find any differences in daily gain between fiber and starch diets. Still, isoenergetic and isonitrogenous high-starch vs. fiber-rich rations that also resulted in similar daily gains and muscle depot induced fatter carcasses with starchy diets in young bulls after 8 mo of fattening (Costa et al., 2013). Increased lipogenesis with starch diets was associated with greater ruminal propionic fermentations and possibly greater starch bypass and greater insulinemia (Majdoub et al., 2003). However, Schoonmaker et al. (2004) also showed that energy source affected hyperplasia, whereas the amount of energy affected hypertrophy of fat tissues, implying that 
the type of energy affects adiposity when applied in the growing phase. In the present trial, $\mathrm{NE}_{\mathrm{g}} \mathrm{I}$ were similar in the 56- to 196-d period for SL and FR bulls, but the energy source of these diets differed. Increased fatness with the SL diet could thus result from a combination of different energy sources fed from the growing postweaning phase onward and nonsignificant differences in $\mathrm{NE}_{\mathrm{g}} \mathrm{I}$ in the last $70 \mathrm{~d}$ of fattening.

Lipid supplementation may influence daily gain, but the literature data do not converge (review by Clinquart et al., 1995). When lipid supplementation using linseed does not result in changes in DMI but increases energy intake, daily gain is either increased (Maddock et al., 2006) or unchanged (Barton et al., 2007). The greater fat content in SL bulls than in FR bulls may be due to lipid supply in addition to starch. The positive effect of dietary lipids on fat percentage in carcasses is frequently observed (Clinquart et al., 1995) but not systematically reproduced (Corazzin et al., 2012). In addition, linseed may have improved feed efficiency, as shown by Maddock et al. (2006), and protein deposition efficiency, thereby increasing the amount of energy to be deposited as fat. Indeed, in growing steers, omega-3 LCFA, which are present in linseed-containing diets, were shown to potentiate the effect of insulin on protein metabolism via the mammalian target of rapamycin (mTOR) signaling pathway and to reduce amino acid oxidation (Gingras et al., 2007).

Interestingly, the efficiency of utilization of digestible $\mathrm{N}$ for muscle depot was greater for the FR diet than for the SL and SLR diets, despite a greater visceral mass. This effect could be strictly attributed to differences in diet composition and/or digestibility. This pattern is opposite that of the efficiency of $\mathrm{CP}$ transfer into milk, which is increased by high-starch diets (Cantalapiedra-Hijar et al., 2014).

\section{Metabolic Indicators}

On a metabolic basis, a better use of nutrients can be achieved either by changes in weights of tissue or organs or by changes in the specific metabolic activity of each tissue or organ (see reviews by Ortigues and Visseiche [1995] and Hocquette et al. [2007]). Genetic selection on residual feed intake (an indicator of feed efficiency) has been shown to regulate the activities of enzymes involved in FA and glucose metabolisms in the liver and in muscle tissue (Le Naou et al., 2012; Faure et al., 2013). Here, where gross feed efficiency (BWG/NE $\mathrm{NE}_{\mathrm{g}}$ ) and partial efficiency of $\mathrm{NE}_{\mathrm{g}}$ use for fat depot differed between FR and SL treatments, we hypothesized differences in muscle and liver energy metabolism activity between the SL and FR bulls. In fact, we observed no difference in specific metabolic activity in the liver and a difference in LDH activity expressed per gram of tissue in only muscles. These limited differences may be explained by several reasons: a difference in the efficiency of muscle or fat gain $(<20 \%$ between SL and FR diets) that was not sufficient to alter metabolic activity, changes in other metabolic pathways (such as protein metabolism) not assessed here, and the implication of other biological mechanisms. However, note that the first enzyme to be regulated is $\mathrm{LDH}$, as reported in pigs (Le Naou et al., 2012). Lactate dehydrogenase plays a pivotal role in the cross talk between skeletal muscle (conversion of glucose into lactate) and liver (neosynthesis of glucose from lactate), and thus an increased Cori cycle has been associated with lower feed efficiency (Le Naou et al., 2012). Another potential mechanism that probably regulates feed efficiency is the lower weight of the empty digestive tract for the SL diet than for the FR diet, which results from a lower fiber intake (Fitzsimons et al., 2014).

\section{Effect of Energy Source on Muscle Fatty Acid Composition}

Improving the nutritional quality of beef is a key challenge for the beef industry. Despite extensive hydrogenation of dietary FA in the rumen, nutritional quality can still be enhanced, especially by a greater deposition of $n$-3 PUFA in muscles to give a greater $n$ $3 / n-6$ ratio in meat (see reviews by Wood et al. [2008] and Doreau et al. [2011]). Here, we report the first evidence of significant effects of muscle type and diet factors on beef total lipids and FA composition in finished cattle in which nutritional conditions varied by the level and chemical nature of dietary energy. Indeed, data reported in the literature on variations of beef lipid and FA characteristics with nutritional factors have mainly concerned the effects of basal diet, especially between grass-fed and concentrate-fed diets differing in $n-6 / n$-3 ratio (Dannenberger et al., 2004; Aldai et al., 2011) and dietary lipid supplements (Raes et al., 2004; Bauchart et al., 2005; Herdmann et al., 2010).

The greater total lipid and FA contents in LT and RA muscles than in ST muscle irrespective of dietary energy characteristics confirmed previous data comparing the nutritional qualities of 9 types of muscles from finishing Charolais cattle (Bauchart et al., 2008). The very significant stimulatory effect of the high dietary energy level on muscle lipid deposition, noted in all studied muscles, has never previously been reported in the bovine species. In contrast, there was a lack of effect of the chemical nature of ingredients (fiber of the FR diet and linseed oil of the SLR diet made isoenergetic to a lower-energy diet) on muscle lipid deposition (noted in all studied muscles), as previ- 
ously reported in cattle given lipid-supplemented diets (Bartoň et al., 2007; Herdmann et al., 2010).

The greater deposition of lipids and of FA observed in muscles of bulls given the SL diet, which was greater in energy, would be explained by a stimulation of lipogenic pathways in intra- and intermuscular adipocytes. The hypothesis of this kind of lipogenic effect was confirmed by the greater contents, in muscle cells, of saturated and monounsaturated FA known to be synthesized preferentially by such adipose cells. On the other hand, the greater deposition of linolenic acid at the expense of linoleic acid in muscles of bulls given linolenic acidrich linseed clearly confirms the capacity of muscle cells to incorporate this dietary $n-3$ PUFA in their lipids, as reported earlier (Noci et al., 2007), thus improving the health value of beef lipids for human consumers.

The intensity of conversion of dietary linolenic acid into $n$-3 long-chain PUFA by reactions of elongation and desaturation in hepatic cells and their subsequent tissue deposition is evaluated by determining EPA, DPA, and DHA contents in muscle cells. Our results clearly showed that EPA, DPA, and DHA were efficiently produced and deposited in muscle tissues, especially in lean (ST) muscle, in finishing bulls given linseed-supplemented diets (SL and SLR diets), thus confirming previous data in meat cattle given different sources of linolenic acid (see Dannenberger et al. [2004], Maddock et al. [2006], and Herdmann et al. [2010] for EPA, DPA, and DHA; see Bartoň et al. [2007] for only EPA and DPA). However, DHA content remained low, showing the low extent of the last desaturation step, which may be due to the low activity of $\Delta 4$-desaturase and to competition between DHA and other LCFA for incorporation in phospholipids (Raes et al., 2004). Additionally, we demonstrate, for the first time, that such metabolic conversion of linolenic acid into LC $n-3$ PUFA is not dietary energy dependent because the greatest muscle deposition of DHA was still observed in bulls fed the energy-restricted SLR diet.

Compared to the FR diet, the SL diet increased the amount of total and all individual cis and trans isomers (except trans-6 18:1 to trans-8 18:1) in all muscles. However, isomer proportions changed: among trans isomers, the coelution of trans-10 18:1 and trans-11 18:1 increased, whereas trans-12 to trans-16 isomers decreased (data not shown). This result is probably due to linolenic acid supply, which has been shown to increase trans-12 18:1 to trans-16 18:1 isomers at the expense of trans -9 18:1 and trans-10 18:1 isomers in bulls fed grass (Dannenberger et al., 2004) and in culled cows fed linseed (Habeanu et al., 2014) compared with animals fed cereal diets. In our trial, trans-9 18:1 did not change, perhaps because of the opposing effects of cereals and linseed.

\section{Conclusion}

One of the novelties of this study was to separate the effects of the source and level of energy intake on fattening performance and carcass responses in bull production. This study compared 2 concentrates differing by the source of energy, based on a mixture of starch and linseed or on fibrous byproducts, and also by the level of energy. Results show that it is possible to modulate performance and meat quality by changing the source of energy in ad libitum-fed diets. Feed efficiency was significantly improved at restricted energy intakes. High dietary energy level increased muscle FA deposition. As expected, the muscle omega-3 FA content was increased by including feeds rich in omega-3 FA, especially in lean (ST) muscle, independent of the dietary energy level.

\section{LITERATURE CITED}

Aldai, N., M. E. R. Dugan, J. K. G. Kramer, A. Martínez, O. LópezCampos, A. R. Mantecón, and K. Osoro. 2011. Length of concentrate finishing affects the fatty acid composition of grassfed and genetically lean beef: An emphasis on trans-18:1 and conjugated linoleic acid profiles. Animal 5:1643-1652.

AOAC. 1990. Official methods of analysis. Vol. 1. 15th ed. Assoc. Off. Anal. Chem., Arlington, VA.

Bartoň, L., M. Marounek, V. Kudrna, D. Bureš, and R. Zahrádková. 2007. Growth performance and fatty acid profiles of intramuscular and subcutaneous fat from Limousin and Charolais heifers fed extruded linseed. Meat Sci. 76:517-523.

Bauchart, D., F. Chantelot, and G. Gandemer. 2008. Qualités nutritionnelles de la viande et des abats chez le bovin: Données récentes sur les principaux constituants d'intérêt nutritionnel. Cah. Nutr. Diet. 43(Hors Ser. 1):1S9-1S39.

Bauchart, D., C. Gladine, D. Gruffat, L. Leloutre, and D. Durand. 2005. Effects of diets supplemented with oil seeds and vitamin E on specific fatty acids of Rectus abdominis muscle in charolais fattening bulls. In: J. F. Hocquette and S. Gigli, editors, Indicators of milk and beef quality. Wageningen Acad. Publ., Wageningen, The Netherlands. p. 431-436.

Bradford, B. J., and C. R. Mullins. 2012. Strategies for promoting productivity and health of dairy cattle by feeding nonforage fiber sources. J. Dairy Sci. 95:4735-4746.

Bradford, M. M. 1976. A rapid and sensitive method for the quantitation of microgram quantities of protein utilizing the principle of protein dye binding. Anal. Biochem. 72:248-254.

Brennan, R. W., M. P. Hoffman, F. C. Parrish, F. Epplin, S. Bhide, and E. O. Heady. 1987. Effects of differing ratios of corn silage and corn grain on feedlot performance, carcass characteristics and projected economic returns. J. Anim. Sci. 64:23-31.

Cantalapiedra-Hijar, G., J. L. Peyraud, S. Lemosquet, E. Molina-Alcaide, H. Boudra, P. Nozière, and I. Ortigues-Marty. 2014. Dietary carbohydrate composition modifies the milk $\mathrm{N}$ efficiency in late lactation cows fed low crude protein diets. Animal 8:275-285.

Carter, J. N., P. A. Ludden, M. S. Kerley, M. Ellersieck, W. O. Herring, and E. Berg. 2002. Intramuscular fat deposition in steers is accelerated at a set body weight. Prof. Anim. Sci. 18:135-140.

Clinquart, A., D. Micol, C. Brundseaux, I. Dufrasne, and L. Istasse. 1995. Utilisation des matières grasses chez les bovins à l'engraissement. INRA Prod. Anim. 8:29-42. 
Coleman, S. W., R. H. Gallawan, W. A. Phillips, J. D. Volesky, and S. Rodriguez. 1995. Silage or limit-fed grain growing diets for steers: II. Empty body and carcass composition. J. Anim. Sci. 73:2621-2630.

Corazzin, M., S. Bovolenta, A. Sepulcri, and E. Piasentier. 2012. Effect of whole linseed addition on meat production and quality of Italian Simmental and Holstein young bulls. Meat Sci. 90:99-105.

Costa, A. S. H., P. Costa, R. J. B. Bessa, J. P. C. Lemos, J. A. Simoes, J. Santos-Silva, C. M. G. A. Fontes, and J. A. M. Prates. 2013. Carcass fat partitioning and meat quality of Alentejana and Barrosa young bulls fed high or low maize silage diets. Meat Sci. 93:405-412.

Dannenberger, D., G. Nuernberg, N. D. Scollan, W. Schabbel, H. Steinhart, K. Ender, and K. Nuernberg. 2004. Effect of diet on the deposition of $n-3$ fatty acids, conjugated linoleic- and C18:1 trans fatty acid isomers in muscle lipids of German Holstein bulls. J. Agric. Food Chem. 52:6607-6615.

Dehority, B. A., and C. G. Orpin. 1997. Development of, and natural fluctuations in, ruminal microbial populations. In: P. N. Hobson and C. S. Stewart, editors, The rumen microbial ecosystem. Chapman and Hall, London. p. 196-245.

Doreau, M., E. Aurousseau, and C. Martin. 2009. Effects of linseed lipids fed as rolled seeds, extruded seeds or oil on organic matter and protein digestion in cows. Anim. Feed Sci. Technol. 150:187-196.

Doreau, M., D. Bauchart, and Y. Chilliard. 2011. Enhancing fatty acid composition of milk and meat through animal feeding. Anim. Prod. Sci. 51:19-29.

Doreau, M., H. P. S. Makkar, and P. Lecomte. 2013. The contribution of animal production to agricultural sustainability. In: J. W. Oltjen, E. Kebreab, and H. Lapierre, editors, Energy and protein metabolism and nutrition in sustainable animal production. Wageningen Acad. Publ., Wageningen, The Netherlands. p. 475-485.

Dulphy, J. P., B. Carle, and C. Demarquilly. 1990. Quantités ingérées et activités alimentaires comparées des ovins, bovins et caprins recevant des fourrages conservés avec ou sans aliment concentré. I. Etude descriptive. Ann. Zootech. 39:95-111.

Faisant, N., V. Planchot, F. Kozlowski, M. P. Pacouret, P. Colonna, and M. Champ. 1995. Resistant starch determination adapted to products containing high levels of resistant starch. Sci. Aliments 15:83-89.

Faure, J., L. Lefaucheur, N. Bonhomme, P. Ecolan, K. Meteau, S. Metayer Coustard, M. Kouba, H. Gilbert, and B. Lebret. 2013. Consequences of divergent selection for residual feed intake in pigs on muscle energy metabolism and meat quality. Meat Sci. 93:37-45.

Favreau-Peigné, A., R. Baumont, and C. Ginane. 2013. Food sensory characteristics: Their unconsidered roles in the feeding behaviour of domestic ruminants. Animal 7:806-813.

Fitzsimons, C., D. A. Kenny, and M. McGee. 2014. Visceral organ weights, digestion and carcass characteristics of beef bulls differing in residual feed intake offered a high concentrate diet. Animal 8:949-959.

Folch, J., M. Lees, and G. H. S. Sloane-Stanley. 1957. A simple method for the isolation and purification of total lipids from animal tissues. J. Biol. Chem. 226:497-509.

Geay, Y., D. Micol, J. Robelin, P. Berge, and C. Malterre. 1987. Recommandations alimentaires pour les bovins en croissance et à 1'engrais. Bull. Tech. CRZV Theix, INRA 70:173-183.

Glass, R. L. 1971. Alcoholysis, saponification and the preparation of fatty acid methyl esters. Lipids 6:919-925.
Gingras, A. A., P. J. White, P. Y. Chouinard, P. Julien, T. A. Davis, L. Dombrowski, Y. Couture, P. Dubreuil, A. Myre, K. Bergeron, A. Marette, and C. Thivierge. 2007. Long-chain omega-3 fatty acids regulate bovine whole-body protein metabolism by promoting muscle insulin signaling to the AKt-mTor-S6K1 pathway and insulin sensitivity. J. Physiol. 579:269-284.

Habeanu, M., A. Thomas, E. Bispo, M. Gobert, D. Gruffat, D. Durand, and D. Bauchart. 2014. Extruded linseed and rapeseed both influenced fatty acid composition of total lipids and their polar and neutral fractions in longissimus thoracis and semitendinosus muscles of finishing Normand cows. Meat Sci. 96:99-107.

Herdmann, A., J. Martin, G. Nuernberg, D. Dannenberger, and K. Nuernberg. 2010. Effect of dietary $n-3$ and $n-6$ PUFA on lipid composition of different tissues of German Holstein bulls and the fate of bioactive fatty acids during processing. J. Agric. Food Chem. 58:8314-8321.

Hoch, T., and J. Agabriel. 2004. A mechanistic dynamic model to estimate beef cattle growth and body composition. I. Model description. Agric. Syst. 81:1-15.

Hocquette, J. F., S. Tesseraud, I. Cassar-Malek, Y. Chilliard, and I. Ortigues-Marty. 2007. Responses to nutrients in farm animals: Implications for production and quality. Animal 1:1297-1313.

INRA. 2007. Alimentation des bovins, ovins et caprins. Besoins des animaux - Valeurs des aliments. Quae Ed., Paris.

Jurie, C., I. Ortigues-Marty, B. Picard, D. Micol, and J. F. Hocquette. 2006. The separate effects of the nature of diet and grazing mobility on metabolic potential of muscles from Charolais steers. Livest. Sci. 104:182-192.

Le Naou, T., N. Le Floc'h, I. Louveau, H. Gilbert, and F. Gondret. 2012. Metabolic changes and tissue responses to selection on residual feed intake in growing pigs. J. Anim. Sci. 90:4771-4780.

Maddock, T. D., M. L. Bauer, K. B. Koch, V. L. Anderson, R. J. Maddock, G. Barceló-Coblijn, E. J. Murphy, and G. P. Lardy. 2006. Effect of processing flax in beef feedlot diets on performance, carcass characteristics, and trained sensory panel ratings. J. Anim. Sci. 84:1544-1551.

Majdoub, L., M. Vermorel, and I. Ortigues-Marty. 2003. Ryegrassbased diet and barley supplementation: Partition of energyyielding nutrients among splanchnic tissues and hind limbs in finishing lambs. J. Anim. Sci. 81:1068-1079.

Mialon, M. M., C. Martin, F. Garcia, J. B. Menassol, H. Dubroeucq, I. Veissier, and D. Micol. 2008. Effects of the forage-to-concentrate ratio of the diet on feeding behaviour in young Blond d'Aquitaine bulls. Animal 2:1682-1691.

Mueller, C. J., H. M. Blalock, and R. H. Pritchard. 2011. Use of soybean hulls as a replacement for dry rolled corn in beef cattle feedlot receiving diets. J. Anim. Sci. 89:4142-4150.

Noci, F., P. French, F. J. Monahan, and A. P. Moloney. 2007. The fatty acid composition of muscle fat and subcutaneous adipose tissue of grazing heifers supplemented with plant oilenriched concentrates. J. Anim. Sci. 85:1062-1073.

Ortigues, I., and M. Doreau. 1995. Responses of the splanchnic tissues of ruminants to changes in intake. Absorption of digestion end-products, tissue mass, metabolic activity and implications to whole energy metabolism. Ann. Zootech. 44:321-346.

Ortigues, I., and A. L. Visseiche. 1995. Whole-body fuel selection in ruminants: Nutrient supply and utilization by major tissues. Proc. Nutr. Soc. 54:235-251.

Piot, C., J. H. Veerkamp, D. Bauchart, and J. F. Hocquette. 1998. Contribution of mitochondria and peroxisomes to palmitate oxidation in rat and bovine tissues. Comp. Biochem. Physiol. B Biochem. Mol. Biol. 121:185-194. 
Provenza, F. D. 1995. Role of learning in food preferences of ruminants: Greenhalgh and Reid revisited. In: W. von Engelhardt, S. Leonhard-Marek, G. Breves, and D. Giesecke, editors, Ruminant physiology: Digestion, metabolism, growth and reproduction. Ferdinand Enke Verlag, Stuttgart, Germany. p. 233-247.

Raes, K., S. de Smet, and D. Demeyer. 2004. Effect of dietary fatty acids on incorporation of long chain polyunsaturated fatty acids and conjugated linoleic acid in lamb, beef and pork: A review. Anim. Feed Sci. Technol. 113:199-221.

Riediger, N. D., R. A. Othman, M. Suh, and M. H. Moghadasian. 2009. A systemic review of the roles of n-3 fatty acids in health and disease. J. Am. Diet. Assoc. 109:668-679.

Robelin, J., and Y. Geay. 1975. Estimation de la composition de la carcasse des taurillons partir de la composition de la 6ème côte. Bull. Tech. CRZV Theix INRA 22:41-44.

Sami, A. S., C. Augustini, and F. J. Schwartz. 2004. Effects of feeding intensity and time on feed on performance, carcass characteristics and meat quality of Simmental bulls. Meat Sci. 67:195-201.
Sharman, E. D., P. A. Lancaster, C. R. Krehbiel, G. G. Hilton, D. R. Stein, U. DeSilva, and G. W. Horn. 2013. Effect of starchvs. fiber-based energy supplements during winter grazing on partitioning of fat among depots and adipose tissue gene expression in growing cattle and final carcass characteristics. J. Anim. Sci. 91:2264-2277.

Schoonmaker, J. P., F. L. Fluharty, and S. C. Loerch. 2004. Effect of source and amount of energy and rate of growth in the growing phase on adipocytes cellularity and lipogenic enzyme activity in the intramuscular and subcutaneous fat depots of Holstein steers. J. Anim. Sci. 82:137-148.

Scislowski, V., D. Durand, D. Gruffat, P. M. Laplaud, and D. Bauchart. 2005. Effects of dietary n-6 and n-3 PUFA on peroxidability of lipoproteins in steers. Lipids 40:1245-1256.

Van Soest, P. J., J. B. Robertson, and B. A. Lewis. 1991. Methods of dietary fiber, neutral detergent fiber, and nonstarch polysaccharides in relation to animal nutrition. J. Dairy Sci. 74:3583-3597.

Wood, J. D., M. Enser, A. V. Fisher, G. R. Nute, P. R. Sheard, R. I. Richardson, S. I. Hughes, and F. M. Whittington. 2008. Fat deposition, fatty acid composition and meat quality: A review. Meat Sci. 78:343-358. 